\title{
National News
}

\section{Forestry and the Internet in Canada}

The Internet is the largest network of computers in the world with approximately 70 million persons connected. The number of users is growing at the astounding rate of $12 \%$ per month! Even conservative estimates put the number of people that will have Internet access by the turn of the century at over 500 million. Of the many attractions of the Internet, the World Wide Web is one of the most appealing. The Web offers the Internet user the opportunity to explore a wealth of information on every conceivable subject - from arts to social science, from environment to culture, from business to government, and from news to environment. Virtually all subjects are covered by the Web, including forestry!

What type of forestry information is on the Web? Just about everything. There are policy papers, forestry legislation, newsletters, conference announcements, databases, organizational profiles, technical bulletins, software, libraries and bibliographies, even maps. Who is putting this information on the Web? Again, every conceivable type of organization - governments, companies, universities, research institutions, NGOs, professional associations, to name a few. In comparison to the United States and Europe, the Canadian forestry sector has been a bit slow to embrace the Web; however, things are changing quickly as more of us are getting online each day.

What follows is a brief look at some of the forestry sites on the Web of interest to the Canadian forestry community.

\section{Federal government}

Natural Resources Canada (http://www. emr.ca/home/nrcanhpe.htm) - The entry point for all of NRC's Web presentations incluidng the Canadian Forest Service: Canadian Wildland Fire Information System, regional centres, the model forest program, and the CFS's gopher menu.

CFAN (http://www.dowco.com/designnet/cfan) - One of the more informative forestry sites on the Web; the CIDA Forestry Advisers Network's site has descriptions of CIDA-supported forestry projects in developing countries and thematic papers on international forestry issues.
Parks Canada (http://parkscanada.pch. gc.ca/main_e.htm) - Take a journey through Canada's national parks and national historic sites, 168 in all, in every corner of the country.

National Atlas Information Service (http://www-nais.ccm.emr.ca/wwwnais/) - An introduction to the services of Geomatics Canada including an overview of their cartographic and geographical names services; has satellite images of Canada showing the forest cover.

\section{Provincial governments}

As part of a general move towards greater public access to information, many provincial governments have opened sites for the ministries responsible for the provincial forests. The sites usually have a message from the Minister, a policy statement, links to department and section sites, publications, and sometimes specific papers on current issues in the sector. Some examples of provincial home pages include:

British Columbia (http://mofwww.for. gov.bc.ca) - BC Ministry of Forests. Ontario Ministry of Natural Resources — (http://govonca3.gov.on.ca/cgi-bin/ MBS/english/common/mfs/03/MNR0917. $\mathrm{html})$.

Quebec Ministry of Natural Resources - (http://www.mrn.gouv.qc.ca/mrn/).

New Brunswick Ministry of Natural Resources and Energy - (http://www. gov.nb.ca/dnre/forest.htm).

\section{NGOS and associations}

Canadian NGOs are well-experienced users of the Internet. A growing number of NGOs, professional associations, cooperatives, and federations are using the Web to capture a wider audience.

\section{Canadian Institute of Forestry} (http://www.episet.com/cif) — The CIF's own Home page provides information on how it is promoting the forestry profession in Canada, membership benefits, listing of national sections, and a membership application.

Western Canada Wilderness Committee (http://www.ccinet.ab.ca/wcwc/) - The home page of the Alberta chapter of this famous environmental activist group.
Ontario Forestry Association (http:// www.vrx.net/oforest) has information on raising awareness and understanding of all aspects of Ontario's forests; includes forestry information and education programs on forest wildfire prevention, private woodlands, Trees Ontario, Project Tree Cover, National Forest Week, and others.

Cariboo Woodlot Association (http://www.netshop.net/ nsardy/woodlot/woodlot.html) - The Association is based in Williams Lake and promotes sound forest management of woodlots in $\mathrm{BC}$ 's interior; links to other $\mathrm{BC}$ and Canadian government sites, weather reports, and will soon have an electronic training course for Junior Woodlot Foresters and Woodlot Managers.

Québec Maple Syrup Producers' Federation (http://www.vir.com/ maplesyrup/sirop.htm) - Home page for more than 11,000 independent producers; information on history of the industry, production techniques, statistics on world production and exports, nutritional values, and fabulous pure maple syrup recipes!

Forest Alliance of BC (http://www.forest.org/) is a coalition of industry, labour, and forest-dependent communities; information on the Alliance's position on the issues facing sustainable forest management in BC.

Canadian Wood Council (http://www. cwc.ca) a national federation representing the solid wood products industry in Canada.

\section{Forestry industry}

Canadian forest product companies have been a bit slow to embrace the internet as a communication tool but things are starting to change. Some companies now have their own sites that present information on the company history, corporate profile, annual report, policy statements product line, media releases, and more. Some examples include:

Slocan Forest Products (http://www.sfp. bc.ca/sfp/index.html).

Domtar Forest Products (http://www. domtar.com/domtar/english/corpmain.htm). 
Tembec Inc. (http://onlink1.onlink. net/cybermall/tembec/menueng.htm).

Western Forest Products (http://www. pacnet.ca/wfp/).

Obviously, there is an enormous potential here for the forestry industry to use the internet to convey their message on forest management and the restructuring of the industry. To date, none of Canada's many forestry consulting firms has decided to use the internet as way of advertising their services.

\section{Educational institutions}

Most of Canada's universities and technical institutions offering a forestry curriculum are now on-line. Their sites provide information on the undergraduate and graduate programs, departments and affiliated programs, facilities, faculty and staff, research programs, publications, and more.

University of Laval (http:/http://sylva.for. ulaval.ca)

University of Alberta (http://www.rr.ualberta/ca)

University of New Brunswick (http:// www.unb.ca/web/forestry)

Lakehead University (http://www.lakeheadu.ca/ forwww/forestry.html)

BCIT Wood Products program (http://www.soe.bcit.bc.ca/soe/protech/wp/)

Sir Sanford Fleming College (http:/gaia. flemingc.on.ca/snr/welcome.htm)

\section{International forestry}

In addition to the Canadian sites, there are many other forestry sites on the Web, particularly from the United States and Europe. The best way to get an overview of what is out there is to log on to the WWW Virtual Library: Forestry (http://www.metla.f//info/vlib/forestry.html) which is managed by the Finnish Forestry Research Institute. This is one of the most popular forestry sites on the Net, with links to sites around the world. Material is organized by the type of site - universities, research, government, NGOs, and commercial site owners. An excellent starting point for international contacts.

Two other global forestry directories are Galaxy: Forestry (http://galaxy. einet.net/galaxy/Engineering-andTechnology/Agriculture/Forestry.html) and the Natural Resources Institutions and Organizations Worldwide (http://
stbox.vt.edu:10021/Y/yfleung/forestry.html).

The Gaia Forest Archives (http://gaial. ies.wisc.edu/research/pngfores/) and the Rainforest Action Network (http://www. ran.org/ran/) are environmental activist organizations that maintain extensive linkages to other sites, publish news about their campaigns, their organizations, canvass for funds, and generally solicit support for their causes.

International Development Research Centre (IDRC) (http://www.idrc.ca) - Based in Canada, IDRC supports forestry and agroforestry research in developing countries; the site describes the organization and its history, program strategy, news and publications, research programs underway, and more.

Centre for International Forestry Research (CIFOR) (http://www.cgiar. org/cifor/) - Located in Indonesia, CIFOR is a new member of the consultative Group on Agricultural Research (CGIR); site has a mission statement, newsletter, publications list, staff directory, announcements of job opportunities, and links to other sites.

International Union of Forestry Research Organizations (http://iufro. boku.ac.at/) - Information on IUFRO working groups, meetings, newsletters, and member organizations.

International Institute for Sustainable Development (http://www.mbnet.mb. ca/linkages/forestry/forest.html) — IISD is based in Winnipeg and manages an electronic clearinghouse for information on the global forest policy debate.
World Conservation Monitoring Centre (http://) - A UK-based site developed jointly by IUCN, UNEP and WWF on biodiversity, tropical forests, and the WCMC's international projects.

Finally, there is a new site on the internet worth mentioning. In February 1996, Canadian Forests (http://www. dowco.com/designnet/canada.forest) was started as a "super-site" or umbrella site for Canadian forests and forestry. At the present time, it is still "under construction" but when fully operational it will provide information on forestry in Canada and give links to all the major sites of government, industry, education and research, NGOs and associations, consultants, service companies and suppliers. In addition to the forestry sector and the Canadian public in general, Canadian Forests is aimed at the Internet users in Canada's trading partners - United States and Europe. It is being actively marketed to these audiences through internet search engines, local media, forestry communities, Canadian missions abroad, and other communication channels. It is expected that Canadian Forests will be another tool to tell the world about Canadian capabilities in forestry and how we are managing our forests.

This has been only a brief glimpse of what is available on forestry on the internet. The only way to appreciate what is out there is to get connected and browse around. The number of sites is growing daily as are the numbers of uses.

John Roper roper@unix.infoserve.net

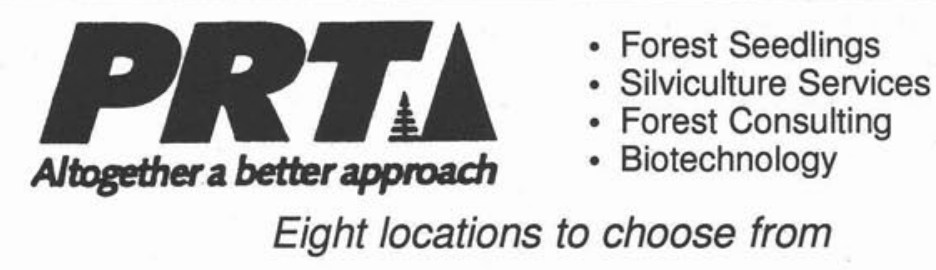

PACIFIC REGENERATION TECHNOLOGIES INC. \#4 - 1028 Fort Street

Victoria, B.C.

V8K 3K4

Tel: (604) 381-1404 Fax: (604) 381-0242 
Forest Products Industry Social and Environmental Performance Research

Research from the Social Investment Organization (SIO), found Canada's forest products industry performs poorly on key social and environmental issues. SIO research also identifies industry leaders on each issue.

Research findings are part of an 8month research program on the industry examining issues such as forest land management, Native affairs, environmental emissions, industrial restructuring and impacts on single industry communities, employment equity, and workforce diversity.

SIO research also highlights a growing sensitivity among senior industry players to the interests of environmentalists, ethical consumers, and special interest groups. This has directly resulted in the recent development of a number of significant and positive corporate social and environmental impact policies, practices, and programs.

The SIO research is published in a three part series and is perhaps the most comprehensive social and environmental assessment of the forestry industry ever undertaken by an independent research organization.

\section{SIO Canadian Forest Products Industry National Roundtable Report \\ Brings together eight industry ana-} lysts who are knowledgeable of, and sensitive to, both the economic and social pressures facing the topic industry. The Roundtable provides expert overviews of key issues affecting the industry.

\section{SIO Canadian Forest Products Industry Focus Report}

The Focus Report is the most comprehensive review of social and environmental issues facing the forest products

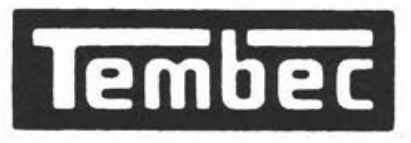
A CIF/IFC Corporate Sustaining Member

industry ever published by a fully independent organization. It features contributions from over 25 key industry representatives and interest groups.

Submissions are brought together in an overview and synthesis by Senior Editor, Lois Dellert, Registered Professional Forester and former Deputy Chief Forester (acting), BC Forest Service.

The SIO Canadian Forest Products Industry Focus Report is a road map of the future social and environmental challenges facing the industry.

\section{SIO Canadian Forest Products Industry Social Investment Profile}

The Social Investment Profile is a condensed report of issues covered in the Roundtable and Focus reports. It offers investors and investment professionals a guide to assessing corporate social and environmental performance against realistic "best practices" given the context of the industry. The Profile identifies industry leaders on each social and environmental issue addressed.

Issues covered include: Community Commitment, Workforce Diversity, Employee Relations, Environment, Native Affairs, Shareholder Rights, Other Issues.

Media copies of the report series along with all Industry Leader designations are available from: The SIO, 366 Adelaide Street East, Suite 443, Toronto, Ontario M5A 3X9. Tel. (416) 360-6047, Fax. (416) 861-0183.

\section{Pulp and Paper Industry Rolls to Profitability}

No PULP FICTION: A jump in newsprint prices returns a battered industry from four straight years of losses.

Canada's pulp and paper companies emerged from four straight years of losses to earn $\$ 4$ billion in 1995 , the industry reported at its annual convention.

The Canadian Pulp and Paper Association is equally upbeat for 1996 , despite a slowdown that started in the final quarter of 1995.

Association economist Kevin McElhatton said the slowdown was a result of sluggish economies in Europe, Japan and the United States.
Customers also began to eat into the paper stocks they had accumulated in anticipation of higher prices, so mills had to cut back and pulp prices dropped.

McElhatton and some executives call this a temporary blip that will be over by midyear. Other industry players expect the slowdown to last a full year.

"The first half is going to be difficult, no doubt," said McElhatton. "The second half should be much stronger. Global demand remains very strong."

\section{Total shipments fall}

Although McElhatton had predicted last year that total pulp and paper shipments from Canadian mills in 1995 would rise by $3-4 \%$, the year-end downturn caused total shipments to fall by $0.8 \%$.

This year he is calling for shipments to rise by $1.8 \%$, with exports to Asia leading the increase.

Other executives and analysts aren't convinced.

Analysts at brokerage firm Levesque Beaubien Geoffrion expect the benchmark kraft pulp price - about $\$ 860$ US a tonne compared with $\$ 985$ in October will drop to $\$ 700$ during the next year because world productive capacity is increasing.

The analysts also suggest a newsprint price increase of $\$ 50$ US a tonne slated for the spring will not stick, and prices may even falter.

The market price is $\$ 825$ US a tonne, almost double that of a low point two years ago.

Ted Boswell, outgoing chairman of the association and president of E.B. Eddy Forest Products, agreed with the more positive outlook, noting there has been very little new capacity added to the Canadian industry, thereby stabilizing prices.

McElhatton said reports by US brokerage firms about new newsprint capacity "are exaggerated."

He noted that in South Korea, although two newsprint machines came on stream last fall and two more will start next fall, that country's growing demand will soon soak up the extra production.

The industry accumulated losses of 5.1 billion between 1991 and 1994 .

Last year, an additional 3,500 people were hired in the industry to bring the average total in 1995 to 246,000 .

The 60 member companies of the association plan to spend $\$ 10$ billion during the next two years to improve efficiency. 


\section{OPFA/CIF Liaison Committee Report - Enhanced Cooperation and Communication}

The purpose of the OPFA/CIF Liaison Committee is to help enhance cooperation and communication between the OPFA and CIF in Ontario.

The committee has been paying close attention to the action items and priorities in their work program plan. The committee met twice through the year in Ottawa in conjunction with meetings of the OPFA Continuing Education Committee. Also, the President, and Committee Chair, attended a meeting with Roxanne Comeau, Executive Director of the CIF, and most of the CIF-Ontario Directors in Halifax in August.

Jim Cayford assembled a package of background information regarding the historical relationship between OPFA and CIF. This material will be drawn on to support committee planning activities. We will make it available to interested members of the OPFA and the CIF upon request.

It is apparent to committee members that more information needs to be shared in a reciprocal relationship between the two organizations. To this end, exchange of articles using the vehicles of The Professional Forester and The Forestry Chronicle is becoming entrenched. Some emphasis will be placed on providing information which compares the mandates and program priorities in both organizations.

The committee is also acting as a catalyst to encourage OPFA Councillors and CIF Directors to hold joint regional meetings instead of separate meetings. This should help bolster attendance and allow for some cross fertilization. It takes into account the demanding schedules of today's resource managers. Councillors and CIF Directors are rising to the challenge and the committee expects that given time this pattern will become ingrained.

OPFA/CIF cooperation has been difficult in the past because there was no CIF-Ontario Coordinator or window to the CIF. Recently, the CIF has agreed that Gord Stone from Sault Ste. Marie will serve in this role. This should help in the movement of information from the OPFA to the CIF-Ontario Sections, and vice versa, and will help strengthen cooperative efforts. Gord has joined the committee and Roxanne Comeau, Executive Director of the CIF, has been most supportive of committee activities.

As a result of committee discussions, plans have been set in motion for a joint CIF/OPFA Conference in Ottawa in October 1996. A planning committee with representation from the OPFA/CIF Liaison Committee has been struck. The theme for this event will be Sustainable Forests: From Theory to Practice. Emphasis will be placed on reporting on progress and also identifying barriers to successful implementation on the ground. Watch for more details in the April edition of The Professional Forester.

By way of a recent member survey, R.P.F.s were asked for their views regarding a joint $C I F / O P F A$ membership option. The Liaison committee will be assessing the results from this portion of the survey in 1996.

Overall, we expect that emphasis will continue in the same areas of committee endeavour in 1996.

Dave Chapeskie, R.P.F., Chair, Peter Murray, R.P.F., Jim Cayford, R.P.F., Richard Macnaughton, R.P.F., Bill Fullerton, R.P.F., Gord Stone, Roxanne Comeau, R.P.F., Laird Van Damme, R.P.F. from OPFA 1995 Annual Report

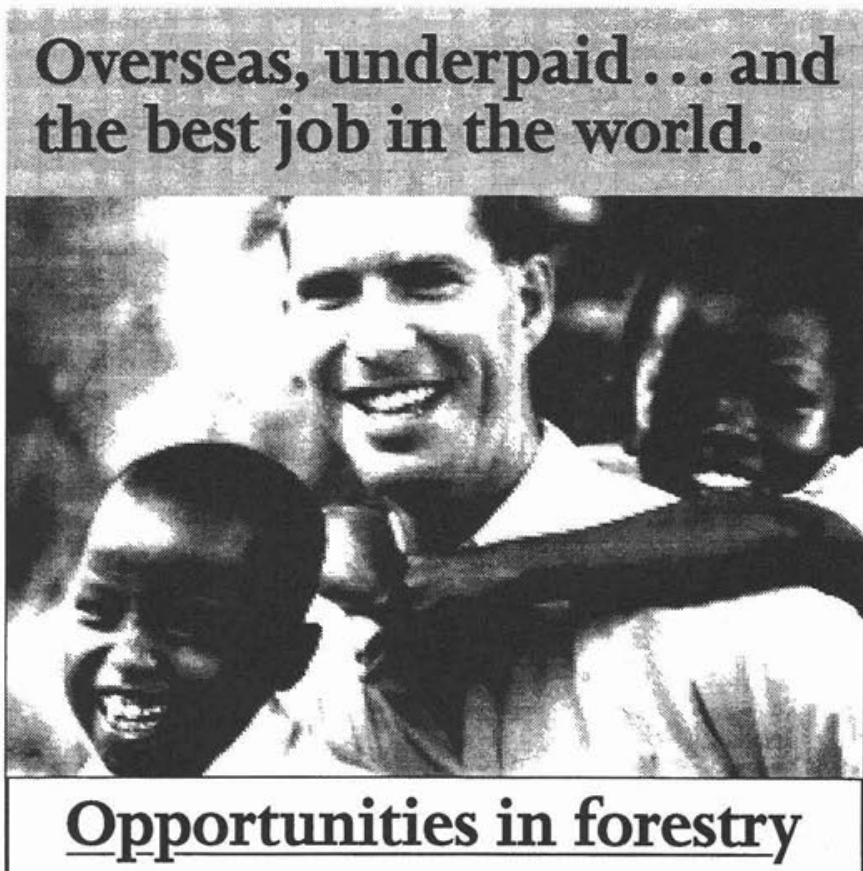

There's nothing 9 to 5 about sharing your skills as a VSO volunteer. It requires commitment, adaptability and the will to live in a challenging culture with few luxuries. At the end of it, you will have gained unique experience and a whole new understanding of global issues.

Jobs in forestry are nearly all involved in helping local rural communities:

Foresters are needed to help with strategic tree planting for fuel-wood and smaller timber - as well as the planting of multi-purpose trees for fruit/nut production and animal fodder. You could also be involved in forest management for environmental protection.

You should have a qualification in a related discipline as well as proven, practical experience. Personal qualities should include adaptability, cultural sensitivity - and a sense of humour.

There are also opportunities for people with forestry degrees to work in forestry planning/development at provincial and national levels.

VSO is the world's largest independent volunteer-sending agency and has been placing Canadians overseas since 1992. Volunteers work alongside local colleagues, sharing their living conditions and receiving a modest living allowance.

Requests for application forms should be made by phone or fax to: (613) 7416588 . Mailing address below.

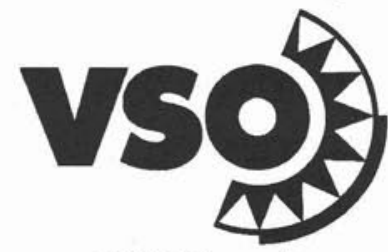

VSO Canada

151 Slater Street - Suite 806 - Ottawa, Ontario K1P 5 H3.

Charity no $1022961-09$

FC

VSO enables men and women to work alongside people in poorer countries in orde to share skills, build capabilities and promote international understanding and action, in the pursuit of a more equitable world. 


\section{Continuing Forestry Education in Québec}

Educators and professional foresters from Eastern Canada met in Québec City on the eve of the referendum to discuss continuing forestry education issues. This mini-conference was funded in part by a grant from Ontario's Ministry of Education. Representatives presented profiles of continuing education activities from each region. This article focuses upon Continuing Forestry Education in Québec.

Laval University, in partnership with Tele-University, offers a Certificate in Forest Management. Five forestry courses and five business administration/management courses make up the certificate package. The forestry courses (developed by Laval University) are delivered in three sessions over weekends in locations suited to groups enrolled in the program. There is also a correspondence component and an excellent text book designed for the forestry courses.

Tele-University supplies the business administration components from some of their existing programs and the entire delivery is print-based correspondence supported by occasional teleconferences and contact with regional helpers.

The cost is about $\$ 50$ per course and is supported by the Ministry of Education in Québec.

This innovative course grew, in large measure, from requests by forest technicians who want to advance their careers in a province where foresters have essentially been licensed to practice. The forest technicians worked as members of the large Corporation des technologues en sciences appliquées to encourage the development of the certificate course.

Ontario has a similar organization of applied science technicians. This association is dominated by engineers, and is rarely supported by forest technicians.

L'Ordre des ingénieurs forestiers du Québec (OIFQ) is moving toward mandatory continuing forestry education. For some time they have had a certificate program similar to the CFE certificate program launched jointly by the OPFA and CIF (see last issue of The Professional Forester).

The OIFQ uses the American trade mark registered "CEU". A CEU is a continuing education unit of 10 contact hours of structured supervised learning activities. An OIFQ certificate is issued when a certain number of CEU's have been earned.
OIFQ's newsletter, l'Aubelle, features a tear-out article devoted to new research or policy. The article concludes with multiple choice and short answer questions that can be completed by members and sent in for credit. This seems to reinforce the message to members about the need for continuing education.

These innovative approaches to CFE compliment government sponsored workshops and other conventional CFE activities that one may find in Ontario and the Maritimes. Of particular interest to the visiting delegation to Québec were the research and technical transfer activities of the Centre d'Enseignement et de Recherche en Foresterie Inc. (CERFO).

CERFO carries out many tasks similar to Ontario's Science and Technology units but is structured differently. They are incorporated non profit organizations based at the technical colleges. The Board of Directors is comprised of representatives from the forest industry and the teaching profession.

The mandate of CERFO is to support the technological development of the forest industry. By locating them at colleges they keep the educational facilities and curricula up to date. CERFO has strong ties to research organizations. They offer services in a cost recovery framework in areas of applied research, training and communications.

Everyone enjoyed the outstanding hospitality of the Québec hosts and the beautiful surroundings. We believe we managed to convince four cab drivers to vote "Non"! Regardless of Québec's destiny with Canada, we can all learn from each other.

Mini-conference Participants: Québec:

Jacques Tremblay (CERFO)

Guy Lessard (CERFO)

Louis Demers (Tele-University)

Suzanne Bareil (OIFQ)

Michel Dessureault (Laval)

Ontario:

Andrew Gordon (U of G)

Jeremy Williams (OAFP)

Bob Elliott (OMNR)

Eileen Harvey (AFPM)

Laird Van Damme (OPFA)

New Brunswick:

John Kershaw (UNB)

Ted Needham (UNB)

Laird Van Damme, R.P.F. The Professional Forester (OPFA)

\section{Protected Areas Strategy, Cornerstone of Sustainability and Biodiversity for Nova Scotia}

Natural Resources Minister Don Downe says the provincial government is ready to develop a protected areas strategy that will be "the cornerstone of our efforts to maintain biodiversity and to achieve sustainable resource development."

Mr. Downe made the remark in Halifax on accepting the report and recommendations of a Public Review Committee on the proposed systems plan for Parks and Protected Areas in Nova Scotia.

The Review committee conducted meetings across Nova Scotia receiving nearly 600 submissions from the public. In its report, the committee says there is widespread public support for the concept of protected spaces and for protection of the 31 candidate sites identified in the proposed plan.

The committee's key recommendation is that all 31 sites be designated as protected areas.

"The 31 sites encompass more than 700 thousand acres or $19 \%$ of all provincial crown land in Nova Scotia," says Mr. Downe. "This is a major commitment, unparalleled across the country in terms of the proportion of Crown land dedicated to protection."

Until the sites are formally designated, the existing moratorium on land and resource use on those sites will remain in effect. The protected areas strategy was expected to be completed this winter.

Mr. Downe says he is pleased that the review committee recommended that wilderness recreational activities, such as hunting and fishing, be permitted within protected areas. He adds that these activities will also be allowed under the moratorium.

Environment Minister Wayne Adams has endorsed the concept of protected areas, as well as the plan to designate the 31 candidate sites for protection.

"Protected natural areas enhance our environment and send an important message to the rest of the world; namely, that we care about sustainability and protection of our natural environment," says Mr. Adams. "Parks and protected areas are one of the greatest legacies we can leave for our children and for future generations." 


\section{Sustainable Forest Management Research Network Launched}

The drine torward sustainable forestsma a sustainable forest industry received a significant boost when Natural Resources Minister Anne McLellan and Secretary of State for Science, Research and Development Jon Gerrard launched a new Network of Centres of Excellence in Sustainable Forest Management (SFM).

Headquartered at the University of Alberta, it links researchers, industry participants and other stakeholders from some 45 organizations across the country.

SFM is one of four newly-created Networks of Centres of Excellence (NCE), joining 10 existing networks selected for renewal in Phase II of the Program.

Total funding for the SFM Network will exceed $\$ 20$ million over four years. Federal funding of $\$ 10.8$ million is being supplemented by $\$ 3.2$ million from the Province of Alberta and a further $\$ 2.2 \mathrm{mil}-$ lion from industry participants. An additional $\$ 4$ million will be raised from existing and new partners.

Forestry is one of Canada's largest industries. It supports more than 339,000 direct forestry jobs and approximately 508,000 indirect wood-based jobs. The industry contributes about $3 \%$ to the national GDP and accounts for $15.2 \%$ of Canada's exports.

Federal funding for the initiative was provided for in the February 1995 budget and built into the existing fiscal framework. It is an example of how the federal government is setting its spending priorities to better serve Canadians by making efficient use of their tax dollars.

\section{New Protected Areas Legislated for British Columbia}

The Government of British Columbia has formalized legal protection for 106 new provincial parks established since 1992. These new parks protect 2.4 million ha of BC wilderness. Included in the Parks Amendment is a commitment by the Government to increase BC's provincial parks to 10 million ha by the year 2000 from the current 6.6 million ha. An additional 2.3 million ha of the Province is protected in national parks, ecological reserves, wilderness reserves and other protective designations.

\section{Swan Valley Forest Capital of Canada 1998}

The Canadian Forestry Association has officially declared the community of Swan Valley, Manitoba the Forest Capital of Canada 1998.

Swan Valley is located in the parkland region of west central Manitoba and incorporates seven villages with a combined population of 25,000 . It is also home to Louisiana-Pacific Canada, Spruce Products, and Roblin Forest Products. Repap and Pine Falls Paper are other major producers in the area.

The Forest Capital designation has been awarded annually by CFA since 1979 , when Hudson Bay, Saskatchewan held the honour. This is the first time a Manitoba community has received the award; every other province except PEI has had at least one community so designated.

CFA President Yves Ouellette, in making the announcement, declared, "Each year we receive submissions from competing areas. The interest the Capital generates is considerable. And there are many spin off-benefits to the winner economic, social and environmental".

The committee from Swan Valley had applied the previous year, but were edged out in the competition by the city of Grande Prairie, Alberta. Said committee chairperson Bernice Palaniuk, "We wanted to come back, to show everyone we deserved the designation".

Each year the community so honoured organizes a series of events to celebrate the title. Swan Valley is no exception. Among the events planned are a children's forestry art contest, a Tree of Life to be decorated by a Seniors group, interactive television lectures, an interpretive program, trappers demonstration, loggers and haulers exhibition, an environmental symposium, and Metis Heritage Days. It is expected the tourism benefits will be substantial.

Each Capital develops a legacy project which will provide longevity to the designation. Swan Valley will be enhancing the Duck Mountain Centre, establishing a public reserve, a park and an arboretum, and constructing Phase II of the Pathway for Active Living.

The current Forest Capital of Canada is Lunenburg, NS, also known as the "Balsam Fir Christmas Tree Capital of the World". Grande Prairie, Alberta is now gearing up for its designation in 1997.

For further information contact Glen Blouin, Canadian Forestry Association (613) 232-1815.

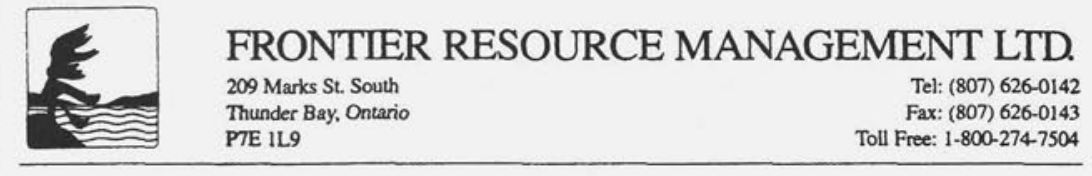

\section{SPECIALIZING IN}

1. Full-service Regeneration Programs

2. Mechanical Cone Collection

3. Seed Extraction

4. Field Surveys and Data Collection

CONTACT

Mike Wood, President

Dave Wood, Vice President 


\section{The Need for a Canadian Federal Presence in Forestry}

The federal government budget must be reduced, and levels of spending be brought under control. This is a vital policy with which we agree. At the same time, the federal government must continue to provide the important leadership and services that are needed in the national interest. This especially applies to those national institutions that serve as unifying agencies. Forestry is one such example in which the federal government has provided those essential trans-regional and international services. We agree that specific functions need to be re-examined, but urge that the critical aspect be sustained.

Canada is a forest nation. Its forests provide significant social, cultural and economic benefits. Forests characterize Canada's landscapes, contribute to its economy, and enrich the lives of every Canadian. Indeed, they are a major component of the Canadian identity. They are essential to the environmental health of the nation, and they are a critical element of Canada's future development.

Canada's forests are as extensive as they are diverse. They extend from sea to sea, and virtually to the northern sea. Almost half (45\%; 419 million ha) of Canada's land is forest. Of that, 236 million ha are considered available for commercial and non-commercial uses. The major forest regions spread across political boundaries. Our great boreal forest, for example, runs from Newfoundland to British Columbia, and north through Yukon and NWT. The forests are comprised of a variety of complex ecosystems. The ecosystems represent extensive biological diversity, help maintain water quality and provide habitat for fish and wildlife. Our forest ecosystems include 131 tree species, over 3,000 species of other plants, about 200 species of mammals, 550 species of birds, 90 different amphibians and reptiles, and many species of insects and other invertebrates.

Most of Canada's forests are publicly owned. Provincial governments are responsible for approximately $71 \%$, while the federal government manages about $23 \%$, largely in the northern territories. The remaining $6 \%$ is made of smaller holdings of about 425,000 private landowners.

Canada's forest industry contributes substantially to the wealth of every province and territory. The forest industry produced over $\$ 43$ billion of products in 1993. Canada exported more than $\$ 22$ billion. All told, the forest industry contributes more to Canada's balance of trade than agriculture, fisheries, mining and energy combined. The industry directly employs approximately 339,000 Canadians and indirectly employs another 508,000 . This means that 1 in 15 Canadians are directly or indirectly employed in forest industries - from tree planter to sawmill worker, Christmas tree grower and farm woodlot owner. Some 350 communities depend entirely or largely on the forest industry.

Canada's forests account for roughly $10 \%$ of the world's forest cover and for almost half of the world's boreal forests. This has particular implications for Canada as its forests are important not only to Canadians but to other people and countries. Globally, Canadian forests contribute significantly to air quality and biodiversity. For these and other reasons, they have become a focus of international attention.

Under our Constitution, forests are the responsibility of the provinces in

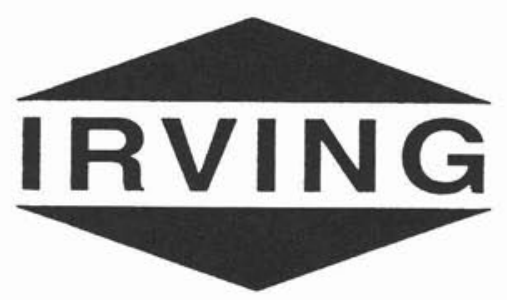

\title{
THE TREE GROWING COMPANY
}

\author{
A CIF/IFC Corporate Sustaining Member
}

which they lie. Provinces and territories have their own forest agencies and have committed, through the Canada Forest Accord, to protect and manage their forests to sustain their environmental, economic, social and cultural values. Maintaining these values helps to meet the needs of the citizens, and revenue generated by forest-based businesses supports provincial economies.

The provinces' research role is primarily short term, operationally orientated and focused on solving the immediate problem. However, there are compelling and historic reasons why a complementary federal presence is also needed. Our concern focuses on the Canadian Forest Service (a sector of Natural Resources Canada) an agency that has proven its worth for almost 100 years since it was established in 1899.

- The federal government is responsible for external affairs - such as trade, commerce, treaties and conventions related to forestry and forest products.

- The federal government is responsible for protection from threats posed by imported insects and disease, and plays an important role in investigation of Canadian forest health. The trans-boundary nature of our forests has given the CFS a unique role in forest research, focusing on strategic issues that require long-term studies, and developing nationally applied programs, such as the forest fire danger rating system, studies in ecosystem dynamics, greenhouse effects and biological control of pests. It also supports the internationally acclaimed Model Forests Program.

Current events illustrated the importance of a national CFS capability to complement provincial and industry activities:

- Forest products trade threats - international negotiations to address restrictions and possible boycotts.

- Non-tariff barrier threats, such as the pinewood nematode.

- Insect and disease threats, such as the recent Asian gypsy moth presence in British Columbia.

- Canadian commitment to Sustainable Forest Management based on ecosys- 
tem processes for which basic and longterm studies will be an essential component.

- Importance of sustaining revenue-generating industries both to support employment, government fiscal needs and trade balances.

Although provinces have responsibility for their forests, approximately $40 \%$ of forestry-generated revenues flow to the federal government through corporate and personal taxes. We believe reinvestment of some of those funds in activities that will help to sustain the benefits we derive from it is essential.

A single national agency provides economies of scale, facilitates a more rapid dissemination of knowledge, provides continuity and prevents duplication. A number of other nations in the world have recognized the need for a national perspective in forestry. For example Finland, France, Sweden, Germany, Mexico, and the United States all maintain forestry agencies at the national level. This demonstrates that Canada's major competitors in the global market have recognized the need for a national perspective in forestry.

\section{The Canadian Institute of}

Forestry/Institut forestier du

Canada strongly believes:

- there are too many vital economic and environmental concerns related to Canada's forest that must continue to be addressed to allow any further reduction in the size and effectiveness of Canada's federal forestry effort,

- that with the current demands on Canada's forests, the present national budget situation, with the changing social values, and increasingly competitive global market, and because Canadian society is demanding greater accountability from its forest mangers at local, national and international levels, a federal forestry presence is needed.

\section{We urge that:}

1. Partnerships such as the Network of Centres of Excellence in Sustainable Forest Management in Alberta be expanded.

2. The CFS be maintained with sufficient strength to fulfil its essential roles in the national and international interests. International credibility will be higher with one, strong, recognized forestry body to deal with issues in trade, environment, quarantine, etc, than having to work with several federal departments.
3. Discussions be initiated with the provinces and forestry sector to explore means to ensure prudent and effective use of the CFS budget, and to negotiate a new arrangement among provinces and industries to extend research and development through to local application.

4. A strong research role be continued with the CFS. Federal research is important in providing forest science information to provinces, in developing the tools and knowledge needed to improve forestry practices, and research does not have provincial borders.

The CIF/IFC would be pleased to contribute our efforts to the process.

(Note: Above was sent to all members of Parliament.)

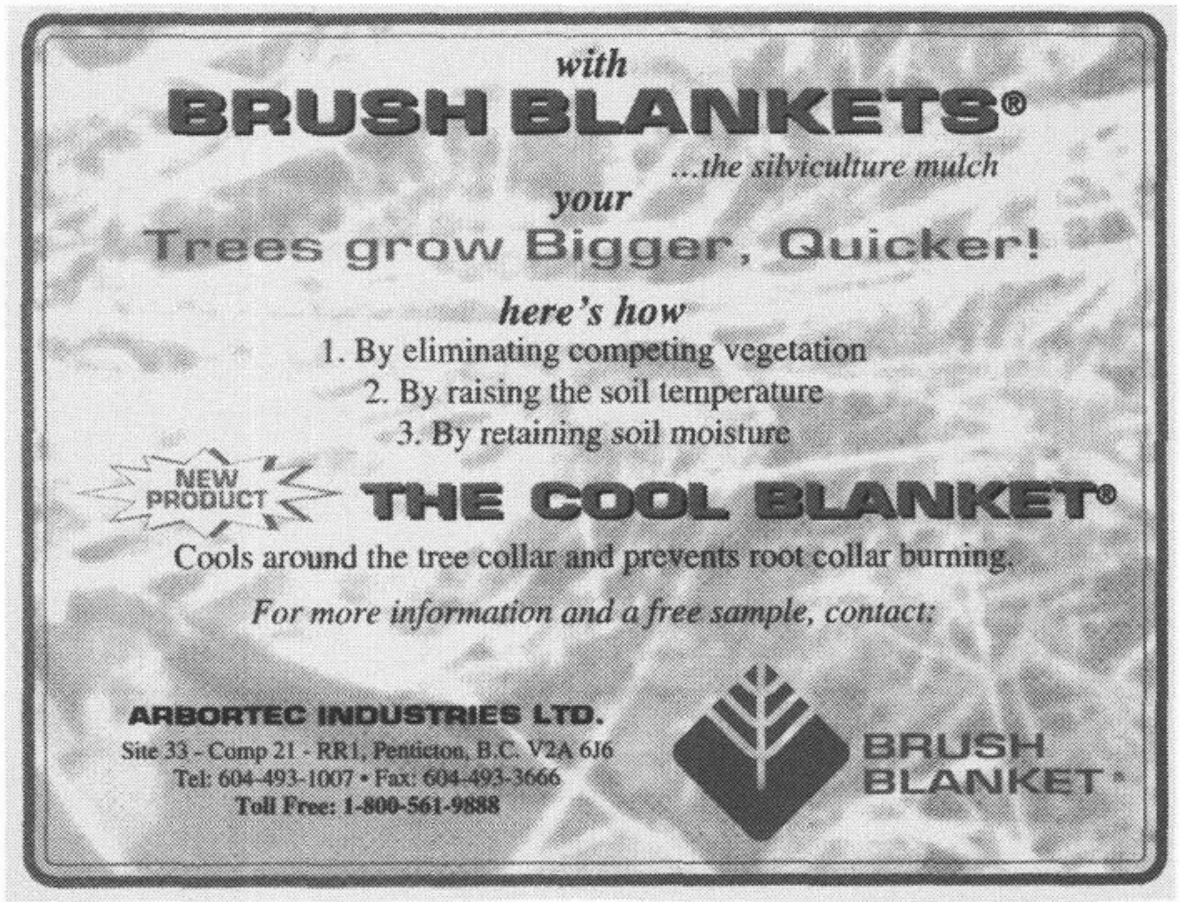

\begin{tabular}{|l|l|}
\hline A Canadian container system that is: \\
- soft-walled for completely natural seedling root formation \\
- always a plug Jiffy \\
- plantable any time after germination \\
- designed to enhance plantation establishment \\
CONTACT: Jiffy Products (N.B.) Limited \\
(roots are air pruned) \\
PO Box 360, Shippagan, N.B., EOB 2PO \\
Phone (506) 336-2284 Fax (506) 336-9609
\end{tabular}




\section{Future of the Petawawa Research Forest}

As the forest science world knows, the Petawawa National Forestry Institute is closing by the fall of 1996 . Over the past year, projects and personnel have been transferred to one or other of the five CFS centres in Fredericton, Quebec, Sault Ste. Marie, Edmonton and Victoria. In all, about a third of the Institute research staff have been offered transfers, and while many of this group are moving, others are exercising retirement or departure options. As well, PNFI support staff (about 80 in all) will be wrapping up their duties by the end of August. At this time, the offices and labs and entire headquarters townsite at PNFI will effectively be closed.

Looking ahead to the future, the Canadian Forest Service is committed to maintaining the forest estate at Petawawa. The plan to install a management team for the Petawawa Research Forest (PRF) is well underway. Four CFS employees from the ranks of the former PNFI make up the basis of the new team. Stephen D'Eon undertakes the role of Forest Manager and Dave Lemkay becomes Development Coordinator. Two others,
Craig Robinson and Peter Copis, add technical expertise in fields of silviculture and genetics, respectively. Rounding out the team, Scientist Emeritus Will Stiell will carry on contributing with his wealth of knowledge. As in the past, summer fire surveillance will be undertaken by students and other specialty operations managed through various contractual arrangements.

The PRF will be retained and managed to keep it widely accessible for research, training and demonstration. The management team will effectively be curators of the living library of forest data and will work to develop durable partnerships and certain commercial enterprise with forestry and scientific communities.

The Petawawa Research Forest is a 100 $\mathrm{km}^{2}$ tract of Great Lakes/St. Lawrence forest situated within Canadian Forces Base Petawawa. It is well known for its hundreds of permanent sample plots and its extensive array of experiments in genetics, plantation establishment, silviculture and fire ecology. The Petawawa Research Forest represents the oldest continuously monitored forest experi- mental area in Canada with data sets dating back to 1917 . In its new life the PRF joins the Acadia Forest and ValCartier Forest in Quebec as the third estate in the experimental forest network of the Canadian Forest Service.

New offices for the PRF are being fitted into the former nursery complex on the shore of Corry Lake. The mailing address for Petawawa will continue as P.O. Box 2000, Chalk River, ON K0J 1J0. It is expected that telephone, fax numbers will remain the same as PNFI. Other electronic addressing will be forthcoming.

Left to Right; Craig Robinson, Peter Copis, Dave Lemkey, Steve D'Eon (missing is Scientist Emeritus, Will Stiell).

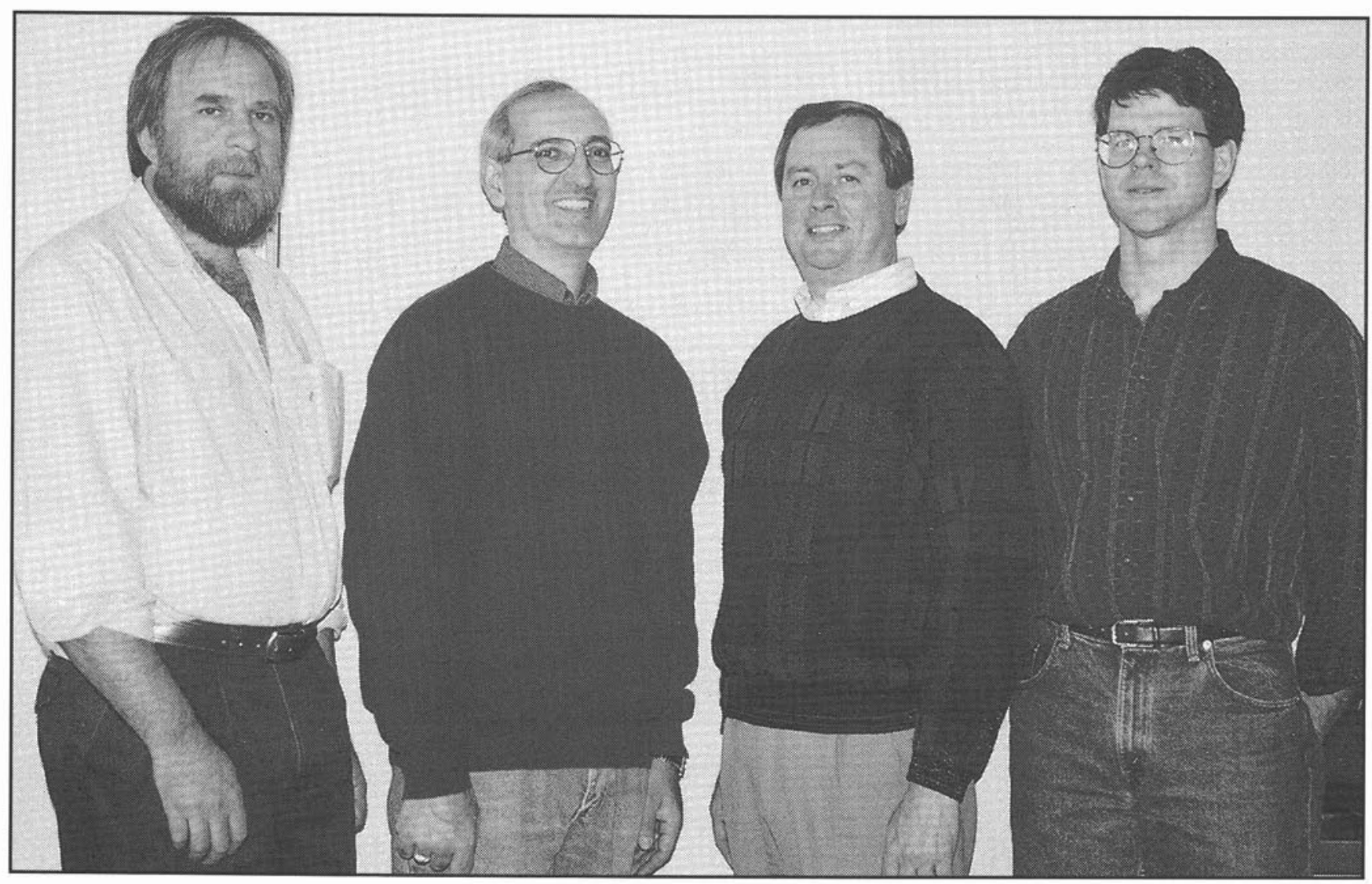

